\title{
Deoxyribonucleic Acid Base Compositions of Mycoplasma Strains of Avian Origin
}

\author{
By W. H. KELTON \\ National Animal Disease Laboratory, Animal Disease and Parasite Research \\ Division, Agricultural Research Service, U.S. Department of Agriculture, \\ Ames, Iowa 500 Io, U.S.A. \\ AND M. MANDEL \\ Department of Biology, The University of Texas, M. D. Anderson \\ Hospital and Tumor Institute at Houston, Houston, Texas 77025, U.S.A. \\ (Accepted for publication I I December 1968)

\begin{abstract}
SUMMARY
The guanine + cytosine (GC) base compositions of deoxyribonucleic acids (DNA) of avian mycoplasmas, as well as strains from other sources, were determined from buoyant density in $\mathrm{CsCl}$. The values from our work ranged from 24.0 to 35.7 moles $\%$. There were small clusters at about $35 \%$ and $32 \%$ but the rest of the values ranged continuously from $24.0 \%$ to $30.5 \%$. From reports in the literature, the values for the Mycoplasma group ranged from $22 \cdot 8$ to $4 \mathrm{I} \cdot \mathrm{O}$.
\end{abstract}

\section{INTRODUCTION}

Knowledge of the mean base composition of deoxyribonucleic acid (DNA) of organisms is an important criterion in classifying species. These techniques, however, have not been applied to the avian mycoplasmas. Nucleic acid homology techniques have been used to determine the lack of relatedness between mycoplasmas and particular bacteria (McGee, Rogul, Falkow \& Wittler, 1965; Rogul, McGee, Wittler \& Falkow, 1965) and to show relationships among the mycoplasmas of human origin (Reich, Somerson, Hybner, Chanock \& Weissman, I966; Reich, Somerson, Rose \& Weissman, 1966). DNA studies were reported at the Second Conference on Biology of the Mycoplasma (N.Y. Academy of Sciences) comparing mycoplasma strains with each other and with L-forms and bacteria (McGee, Rogul \& Wittler, 1967; Neimark, 1967; Somerson, Reich, Chanock \& Weissman, 1967).

This study was undertaken to determine the guanine + cytosine (GC) contents of the DNA of mycoplasmas and to contribute data that may lead to more precise classification of these organisms.

\section{METHODS}

The sources of some strains have been reported (Kelton, Gentry \& Ludwig, I960; Kelton \& Van Roekel, 1963). The three bovine strains were obtained from Drs Edward and Leach, the Wellcome Research Laboratories, Beckenham, Kent, England; the porcine strain, Mycoplasma granularum, from Dr W. Switzer, Iowa State University; M. gallisepticum strains 80I, IOIO and II50 from Dr H. Yoder, Iowa State 
University; $M$. meleagridis strain 529 from Dr R. Yamamoto, University of California, Davis. The strains representing avian serotypes $\mathrm{I}, \mathrm{J}, \mathrm{K}, \mathrm{L}$, and $\mathrm{M}$ were obtained from Dr M. Frey, Iowa State University, and $M$. synoviae strain 1853 from Dr N. Olsen, West Virginia University. Strain 4330 is designated M. hominis, type I (Morton \&

Table I. DNA base compositions of Mycoplasma strains of avian origin

\begin{tabular}{|c|c|c|c|c|}
\hline Species & Strain & Serotype & $\begin{array}{c}\mathrm{CsCl} \text { buoyant } \\
\text { density } \\
\left.\left(\mathrm{g} . / \mathrm{cm}^{3}\right)^{3}\right)\end{array}$ & $\begin{array}{c}\text { GC content } \\
(\text { mole } \%)\end{array}$ \\
\hline M. gallisepticum & $80 I$ & A & $I \cdot 695$ & $35 \cdot 7$ \\
\hline M. gallisepticum & PG-3 I & A & $I \cdot 695$ & $35 \cdot 7$ \\
\hline M. gallisepticum & 1010 & A & I. 695 & $35 \cdot 7$ \\
\hline M. gallisepticum & $s-6$ & A & $1 \cdot 6945$ & $35 \cdot 2$ \\
\hline M. gallisepticum & 1150 & A & $\mathrm{I} \cdot 694$ & 34.7 \\
\hline M. synoviae & 1853 & $\mathbf{S}$ & $I \cdot 6935$ & $34 \cdot 2$ \\
\hline Mycoplasma sp. & 694 & $\mathrm{~L}$ & $I \cdot 6915$ & $32 \cdot 1$ \\
\hline Mycoplasma sp. & $T U$ & $\mathrm{C}$ & $1 \cdot 6899$ & $30 \cdot 5$ \\
\hline Mycoplasma sp. & $\mathrm{C}$ & $\mathrm{C}$ & $1.6885^{*}$ & $29 \cdot I$ \\
\hline$M$. iners & o & G & $1 \cdot 689$ & $29 \cdot 6$ \\
\hline$M$. iners & $P G=30$ & G & $1 \cdot 6885$ & $29 \cdot 1$ \\
\hline Mycoplasma sp. & PSU-4 & D & $\mathrm{I} \cdot 688^{*}$ & $28 \cdot 6$ \\
\hline Mycoplasma sp. & NY & D & $I \cdot 6875$ & $28 \cdot I$ \\
\hline M. meleagridis & 529 & $\mathbf{H}$ & $\mathrm{I} \cdot 688$ & $28 \cdot 6$ \\
\hline M. meleagridis & $\mathrm{N}$ & H & $I \cdot 6875$ & $28 \cdot I$ \\
\hline M. gallinarum & $54-537$ & B & I. 6865 & $27 \cdot 0$ \\
\hline M. gallinarum & PG-16 & B & $\mathrm{I} \cdot 686$ & $26 \cdot 5$ \\
\hline Mycoplasma sp. & SA & $\mathbf{F}$ & $I \cdot 686$ & $26 \cdot 5$ \\
\hline Mycoplasma sp. & 693 & $J$ & $1 \cdot 685$ & $25 \cdot 5$ \\
\hline Mycoplasma sp. & $R-49$ & $\mathrm{M}$ & $\mathrm{I} \cdot 6845$ & 25.0 \\
\hline Mycoplasma sp. & 695 & I & $\mathrm{I} \cdot 684$ & $24 \cdot 5$ \\
\hline Mycoplasma sp. & 1805 & $\mathbf{K}$ & $I \cdot 684$ & $24 \cdot 5$ \\
\hline Mycoplasma sp. & HPR-I 5 & $\mathbf{E}$ & $1 \cdot 6835$ & $24^{\circ} 0$ \\
\hline
\end{tabular}

* Average of four determinations; all others, average of two determinations.

Table 2. DNA base compositions of Mycoplasma strains other than avian

\begin{tabular}{|c|c|c|c|c|}
\hline Species & Strain & Origin & $\begin{array}{c}\mathrm{CsCl} \\
\text { buoyant } \\
\text { density } \\
\left(\mathrm{g} . / \mathrm{cm} .^{3}\right)\end{array}$ & $\begin{array}{c}\text { GC } \\
\text { content } \\
(\text { mole } \% \text { ) }\end{array}$ \\
\hline $\begin{array}{l}\text { Mycoplasma } \mathrm{sp} . \\
\text { (saprophyte) }\end{array}$ & PG-IO & Bovine & $I \cdot 6935$ & $34 \cdot 2$ \\
\hline $\begin{array}{l}\text { Mycoplasma } \mathrm{sp} \\
\text { (saprophyte) }\end{array}$ & $c-15$ & Compost & $I \cdot 692$ & $32 \cdot 7$ \\
\hline $\begin{array}{l}M \text {. arthriditis } \\
(M \text {. hominis, type } 2)\end{array}$ & 07 & Human & $1 \cdot 6915$ & $32 \cdot 1$ \\
\hline $\begin{array}{l}\text { M. arthriditis } \\
(M . \text { hominis, type } 2)\end{array}$ & 39 & Human & I. 69 I 5 & $32 \cdot 1$ \\
\hline M. granularum & & Porcine & 1.6915 & $32 \cdot 1$ \\
\hline M. maculosum & $P G-15$ & Canine & $1 \cdot 689$ & $29 \cdot 6$ \\
\hline M. spumans & $P G-13$ & Canine & $I \cdot 6885$ & $29 \cdot 1$ \\
\hline$M$. canis & $P G-I 4$ & Canine & $\mathrm{I} \cdot 6885^{*}$ & $29 \cdot I$ \\
\hline M. bovigenitalium & PG-I I & Bovine & $\mathrm{I} \cdot 6875$ & $28 \cdot 1$ \\
\hline M. hominis, type I & 4330 & Human & $\mathrm{I} \cdot 686$ & $27 \cdot 3$ \\
\hline M. bovirhinis & PG-43 & Bovine & $\mathrm{I} \cdot 684$ & $24 \cdot 5$ \\
\hline
\end{tabular}

* Average of four determinations; all others, average of two determinations. 
Roberts, 1967) and strains 07 and 39 are designated $M$. arthriditis ( $M$. hominis, type 2) (Edward \& Freundt, 1965). All strains were purified as described previously (Kelton \& Van Roekel, 1963).

In general, 2 l. batches of broth medium (Kelton \& Van Roekel, I 963) or more were inoculated with Io $\mathrm{ml}$. of $48 \mathrm{hr}$ culture/1. and incubated at $37^{\circ}$ on a rotary shaker at approximately $90 \mathrm{rev} . / \mathrm{min}$. until visible turbidity developed. The organisms were separated from the medium by centrifugation at $7500 \mathrm{~g}$, washed once with $0.15 \mathrm{M}-\mathrm{NaCl}$ plus $\mathrm{O} \cdot \mathrm{I}$ M-sodium ethylenediaminetetra-acetate, and resuspended in a small volume of the same buffer. With Mycoplasma synoviae the broth medium was supplemented with L-cysteine hydrochloride hydrate (Calbiochem) and nicotinamide adenine dinucleotide (Pabst Laboratories) each in final concentration of $0.01 \%$.

The organisms were lysed by adding sodium dodecyl sulphate to I \% (w/v) and the DNA was isolated by the method of Marmur (I96I) as modified by Mandel, Bergendahl \& Pfennig (1965). The base composition was estimated from buoyant density in $\mathrm{CsCl}$ in an analytical centrifuge (Schildkraut, Marmur \& Doty, I96r). Buoyant densities were calculated relative to DNA of Escherichia coli at a density of $\mathrm{I} \cdot 7 \mathrm{IO} \mathrm{g}$./ $\mathrm{cm}^{3}$.

\section{RESULTS}

Buoyant densities and base compositions of DNA samples derived from strains of avian origin are shown in Table I. Strains from other sources were included in this study: results from these strains are shown in Table 2.

The GC content of the DNA samples ranged from 24.0 to $35 \cdot 7$ moles $\%$. There was a small cluster of values at about $35 \%$ and another at $32 \%$, but the rest of the values formed a continuous gradation from $24 \cdot 0$ to $30 \cdot 5 \%$.

\section{DISCUSSION}

In grouping micro-organisms the GC content appears to be most useful when the values are different. Similar values were obtained from mycoplasmas that are apparently unrelated. Mycoplasmas arthriditis (M. hominis, type 2) of human origin had the same GC content as $M$. granularum of porcine origin, and the value for the saprophyte, C-I 5, was only slightly higher. Likewise, within the avian group, serotypes A and S gave similar values and there were only minor differences among the values for serotypes B, C, D, F, G, and $\mathrm{H}$. In the studies by McGee et al. (1967) the relationships of five strains having GC content of $32 \%$ were studied by DNA-DNA hybridization. They found that these five strains fell into three unrelated groups and attributed the similar base ratios to chance.

Strains representing I 5 serotypes of avian Mycoplasma were included in this study. Despite repeated attempts, DNA suitable for analysis could not be obtained from strain L 3-IO, representing serotype Q.

In previous studies (Kelton \& Van Roekel, 1963) serological relatedness was demonstrated between serotype E (strain HPR-I5) and serotype G (strains PG-30 and $O$ ) and these strains were included in the same serotype. Dierks, Newman \& Pomeroy (1967) presented similar results in their serological studies of the avian mycoplasmas. The GC contents of the DNA of these strains, however, do not indicate any relationship between these serotypes. 
Table 3. DNA base compositions of Mycoplasma strains reported in the literature

\section{Species \\ M. pneumoniae}

M. gallisepticum

M. agalactiae

$M$. hominis

$M$. hominis, type 2

M. arthriditis

Mycoplasma sp.

M. laidlawii, type A

M. laidlawii, type B

M. granularum

$M$. bovigenitalium

$M$. hominis, type I

M. canis

M. spumans

Mycoplasma sp.

M. gallinarum

Mycoplasma sp.

$M$. fermentans

M. pulmonis

$M$. hyorhinis

$M$. pharyngis

M. maculosum

$M$. orale, type $\mathrm{I}$

$M$. orale, type 2

$M$. mycoides var. mycoides

Mycoplasma sp.

M. mycoides var. capri

Mycoplasma sp.

M. salivarium

$M$. neurolyticum

$M$. neurolyticum
Human

Strain and source

FH, human

ATCC-I 5377, human

BRU, ATCC-I 5377, human

A 5969, avian

A 5969 , avian

Avian

A 5969, avian

ATCC-1 5302 , avian

S-6, ATCC-I 5302, avian

Goat milk

H 39, human

CAMPO, ATCC-I 4152 , human

H 606, ATCC-1 3988

DONNETTA, bovine

ATCC- 14089

SEWAGE

ATCC-I 4192

BTS-39, ATCC-I9168, porcine

PG-I I, ATCC-14173, bovine

H-34, ATCC-1 5056, human

PPLO-4387, ATCC-14027, human

PG-I4, canine

PG-I3, canine

NEGRONI, human

ATCC-1 5319, avian

PG-I6, ATCC-I 53I9, avian

GDL

GII, ATCC-I 5474, human

$\mathrm{G}$, human

KON, ATCC- 14267 , human

BTS-7, ATCC-1 7981, porcine

LGM, ATCC-19524, human

PG-I 5, canine

823 B, ATCC-I 5539, human

DC-I600, human

bovine

v 5, bovine

Calf

Calf

PG-3, goat

Kid strain, goat

Kid

MANIRE, human

KSA, ATCC-I 5049, mouse

Type A, mouse
GC

(mole \%) Method* Reference

39-4I B, C Neimark \& Pene, I965

$39 \cdot 0,40 \cdot 8 \quad$ B, C $\quad$ Neimark, 1967

39.3 B $\quad$ McGee et al. 1965

38.6 B McGee et al. 1967

35.0 B Marmur \& Doty, I 962

34.0 C $\quad$ Schildkraut et al. 1961

33.4, 33.7 B, C Morowitz et al. 1967

33.0-33.5 A, C Morowitz et al. 1962

32.5 B Rogul et al. 1965

32.0 B $\quad$ McGee et al. 1967

$33.6,34.2 \quad$ B, C Neimark, 1967

33.7, 31.6 B, C Morowitz et al. 1967

3I.7 $\quad$ B $\quad$ McGee et al. 1967

$31.9 \quad$ B $\quad$ McGee et al. I967

30.0, 32.6 B, C Morowitz et al. 1967

32.9 B $\quad$ Morowitz et al. 1967

32.5 B McGee et al. 1967

3I.7, 35.7 B, C Neimark, 1967

34.I B $\quad$ Morowitz et al. 1967

3I.0-35.5 B, C Neimark \& Pene, I965

32.3 B $\quad$ McGee et al. 1967

33.2, 33.7 B, C Morowitz et al. 1967

30.4 B $\quad$ McGee et al. 1967

29.6 B $\quad$ McGee et al. 1967

29.2 B $\quad$ McGee et al. 1967

28.7 B $\quad$ McGee et al. 1967

28.4 B $\quad$ McGee et al. 1967

28.4 B $\quad$ McGee et al. 1967

28.3 B $\quad$ McGee et al. 1967

28.0 B Rogul et al. 1965

27.5 B $\quad$ McGee et al. 1967

27.8 $\quad$ B $\quad$ McGee et al. 1967

27.8 B $\quad$ McGee et al. 1967

$27.6 \quad$ C $\quad$ Neimark, I967

27.5 B $\quad$ McGee et al. 1967

27.3 B $\quad$ McGee et al. 1967

$27^{\circ} 0 \quad$ B $\quad$ McGee et al. 1967

26.7 B $\quad$ McGee et al. 1967

26.6 B $\quad$ McGee et al. 1967

26.4 B $\quad$ McGee et al. 1967

$26 \cdot 8,26 \cdot 5 \quad$ B, C Neimark, I967

26. I B $\quad$ McGee et al. 1967

$23 \cdot 6,26 \cdot 5 \quad$ B, C Neimark, 1967

23.5-26.5 B, C Neimark \& Pene, 1965

24-26 A

$24 \cdot \mathrm{I}, 25 \cdot 5$

$24 \cdot 0-25 \cdot 5$

$23 \cdot 3$

$23 \cdot 0$

$22 \cdot 8$
Jones \& Walker, 1963

Jones et al. 1965

B, C Neimark, 1967

B, C Neimark \& Pene, 1965

B McGee et al. 1967

B McGee et al. 1967

C Neimark, 1967

* A, by hydrolysis and chromatography; B, by thermal denaturation-absorbance measurement; $\mathrm{C}, \mathrm{by} \mathrm{CsCl}$ density gradient centrifugation. 
The reports in the literature (Table 3 ) indicate a range of values for the Mycoplasma group from $22 \cdot 8$ to $4 \mathrm{I} \cdot 0$ moles $\%$. Mycoplasma pneumoniae sets apart with reported values from 38.6 to $4 \mathrm{I} \%$ while the others present a continuous gradation from $22 \cdot 8 \%$ to $35.0 \%$.

The technical assistance of Mrs Janet Bergendahl is gratefully acknowledged.

\section{REFERENCE}

Edward, D. G. ff. \& Freundt, E. A. (1965). A note on the taxonomic status of strains like 'Campo' hitherto classified as Mycoplasma hominis type 2. J. gen. Microbiol. 4I, 263.

Dierks, R. E., Newman, J. A. \& Pomeroy, B. S. (I967). Characterization of avian Mycoplasma. Ann. N.Y. Acad. Sci. 143, 170.

JONES, A. S. \& WALKER, R. T. (1963). Isolation and analysis of the deoxyribonucleic acid of Mycoplasma mycoides var. capri. Nature, Lond. 198, 588.

Jones, A. S., Tirtenson, J. R. \& WALker, R. T. (1965). The chemical composition of the nucleic acids and other macromolecular constituents of Mycoplasma mycoides var. capri.J. gen. Microbiol. 40, 405 .

Kelton, W. H. \& VAN Roekel, H. (1963). Serological studies of mycoplasma (PPLO) of avian origin. Avian Dis. 7, 272.

Kelton, W. H., Gentry, R. F. \& Ludwig, E. H. (1960). Derivation of Gram positive cocci from pleuropneumonia-like organisms. Ann. N.Y. Acad. Sci. 79, 4 IO.

Mandel, M., Bergendahl, J. C. \& Pfennig, N. (1965). Dexoyribonucleic acid base composition of isolates of the genus Chlorobium. J. Bact. 89, 917.

Marmur, J. (1961). A procedure for the isolation of deoxyribonucleic acid from micro-organisms. J. molec. Biol. 3, 208.

Marmur, J. \& Doty, P. (1962). Determination of the base composition of deoxyribonucleic acid from its thermal denaturation temperature. J. molec. Biol. 5, 109.

McGee, Z. A., Rogul, M. \& WitTLeR, R. G. (1967). Molecular genetic studies of relationships among mycoplasma, L-forms and bacteria. Ann. N.Y. Acad. Sci. 143, 2 I.

McGee, Z. A., Rogul, M., Falkow, S. \& Wittler, R. G. (1965). The relationhip of Mycoplasma pneumoniae (Eaton agent) to Streptococcus MG: application of genetic tests to determine relatedness of L-forms and PPLO to bacteria. Proc. natn. Acad. Sci. U.S.A. 54, 457.

Morowitz, H. J., Bode, H. R. \& KIRK, R. G. (1967). The nucleic acids of mycoplasma. Ann. N. Y. Acad. Sci. r43, I 10.

Morowitz, H. J., Tourtellotte, M. E., Guild, W. R., Castro, E., Woese, C. \& Cleverdon, R. C. (1962). The chemical composition and submicroscopic morphology of Mycoplasma gallisepticum, Avian 5969. J. molec. Biol. 4, 93.

Morton, H. E. \& RoberTs, R. J. (1967). Properties of Mycoplasma hominis 4330. J. Bact. 93, 71 I.

Neimark, H. (1967). Heterogeneity among the mycoplasma and relationships to bacteria. Ann. N.Y. Acad. Sci. 143, 31.

Neimark, H. C. \& Pene, J. J. (1965). Characterization of pleuropneumonia-like organisms by deoxyribonucleic acid composition. Proc. Soc. expt. Biol. Med. r18, 517.

Reich, P. R., Somerson, N. L., Rose, J. A. \& Weissman, S. M. (1966). Genetic relatedness among mycoplasmas as determined by nucleic acid homology. J. Bact. 91, I53.

Reich, P. R., Somerson, N. L., Hybner, C. J., Chanock, R. M. \& Weissman, S. M. (1966). Genetic differentiation by nucleic acid homology. I. Relationships among mycoplasma species of man. J. Bact. 92, 302.

Rogul, M., MCGee, Z. A., Wittler, R. G. \& Falkow, S. (1965). Nucleic acid homologies of selected bacteria, L-forms and Mycoplasma species. J. Bact. 9o, 1200.

Schildkraut, C. L., Marmur, J. \& Doty, P. (I961). Determination of the base composition of deoxyribonucleic acid from its buoyant density in CsCl. J. molec. Biol. 4, 430.

Somerson, N. L., Reich, P. R., Chanock, R. M. \& Weissman, S. N. (1967). Genetic differentiation by nucleic acid homology. III. Relationships among mycoplasma, L-forms and bacteria. Ann. N.Y. Acad. Sci. 14, 9. 